\title{
䅺
}

\section{Pastoral counselling: towards a diagnostic and interpretational approach in Africa}

\author{
Vhumani Magezi \\ Practical Theology \& Old Testament \\ Bible Institute of South Africa \& George Whitefield College \\ MUIZENBERG \\ E-mail: vhumani@hotmail.com
}

\begin{abstract}
Pastoral counselling: towards a diagnostic and interpretational approach in Africa

Effective pastoral counselling is influenced by appropriate pastoral diagnosis. A pastoral diagnosis or assessment in Africa should focus on socio-cultural systems thinking, which entails an understanding of the people's worldview of distress embedded in stories. Thus, the process of assessment in Africa should concentrate, among other factors, on the constructive and destructive role of the community and the strength of beliefs in supernatural causes of distress in order to focus the probing and interpretation of the conversation.
\end{abstract}

\section{Opsomming}

Pastorale berading: 'n diagnostiese en interpretasiebenadering in Afrika

Effektiewe pastorale berading word beïnvloed deur toepaslike pastorale diagnose. 'n Pastorale diagnose in Afrika behoort te fokus op sosio-kulturele sisteemdenke, wat die verstaan van mense se wêreldbeskouing van nood, ingebed in stories, behels. Daarom moet die proses van ondersoek in Afrika konsentreer op onder meer die konstruktiewe en destruktiewe rol van die gemeenskap, en die krag van geloof in bonatuurlike oorsake van nood, om sodoende die ondersoek en interpretasie van die gesprek te fokus.

\section{Introduction}

Pastoral care and pastoral counselling are phrases that are often used interchangeably but it can also be differentiated. Pastoral care 
assumes pastoral counselling and vice versa. One cannot carry out pastoral counselling without providing pastoral care. Conversely, in pastoral caring the individual is nurtured, and this involves pastoral counselling. Lartey (1997:19) states that these activities refer to an age-old activity known as cura animarum (cure of souls). The context of pastoral care and counselling is the community of faith; the goal is faith and spiritual development; and the method is communication of gospel promises that are applied by the Holy Spirit.

Although pastoral care and counseling are intertwined, they need to be distinguished. A distinction helps to clarify the different focal functions of the activities and avoid confusion. The line of difference between the two is that whereas pastoral care refers to the broad caring activities, pastoral counselling emphasises pastoral caring in the form of dialogue and communication to alleviate distress within the context of pastoral ministry. Benner (1992:14-15) usefully locates pastoral care and counselling within the context of pastoral ministry and explains the difference as follows:

Much as pastoral ministry is broader than pastoral care, so too is pastoral care broader than pastoral counselling. And to attempt to reduce all pastoral care to counselling is to fail to recognize both the breadth of pastoral care as well as the distinctive nature of counselling.

Clinebell (1984:26), one of the most articulate pastoral care theologians, advances a more useful distinction of pastoral care and counselling in his basic definition of terms. He explains that pastoral care is the broad, inclusive ministry of mutual healing and growth within a congregation and its community, through its life cycle. Pastoral counselling, then, as an aspect of pastoral care, is the utilisation of a variety of healing (therapeutic) methods to help people handle their problems and crises in a more developmental way, and in doing so experience healing of their brokenness. Pastoral counselling is a reparative function needed when the growth of individuals is seriously jeopardised or blocked by crises. People may need pastoral counselling in times of severe crises, usually on a short-term basis, but pastoral care is needed for a lifetime. Clinebell rightly views pastoral counselling as an intervention episode in the life of a parishioner when a crisis sets in. The intervention is an attempt to restore the growth process, which would have been obstructed by a crisis. In addition, Crabb (1979:22) observes that the reason why people seek counselling is to remove obstacles in the path of Christian growth. 
Louw (1998:260) states that pastoral counselling as pastoral care is specifically connected to the pastor and describes a more structured method of dealing with issues in a professional way. Pastoral counselling differs from generic Christian counselling offered by ordinary Christians in that it is identified with a pastoral role but the principles that undergird them are the same. The distinction, however, is a functional one. In pastoral counselling the accent is placed on the uniqueness of the relationship between pastor and parishioners within the context of communio sanctorum.

The term pastoral refers to the support system of the communio sanctorum, which has as its main focus the development of faith, the enhancement of Christian spirituality and empowerment of parishioners' faith by conveying organically the fulfilled promises of the gospel. An organic approach interprets the gospel within the actual relationships, contexts, and life issues. The story of salvation is linked to the story of parishioners' struggle, agony and suffering.

Consequently, within the African context where life is perceived holistically, an organic approach is crucial. An individual is perceived to be in a continuous relationship with his community and the supernatural world, both of which has a distinct infuence on the idividual's life. The joys, struggles, and sufferings are interpreted within this schema of relationship networks and there ought to be an equilibrium between individuals and their environment. Disturbing this balance causes sickness and suffering (Mwaura, 2000). This supernatural perception of sickness and suffering poses a pastoral care challenge in Africa and the pastoral counsellor may need to interpret God in terms of these supernatural perceptions and experiences. An understanding of this worldview therefore is crucial for effective and meaningful pastoral diagnosis and hence, for pastoral counselling. Louw (1998:300) correctly maintains that it is not an overstatement to claim that pastoral diagnosis and pastoral counseling are inextricably linked. 1

But could there be a diagnostic and analytical framework to guide pastoral counselling in Africa? How can pastoral assessment and interpretation be clarified and informed by a thorough knowledge of the African worldview?

$1 \quad$ In his doctoral thesis, Magezi (2005:167) argues that diagnosis and counselling are two sides of the same coin which cannot be separated from each other. 
In response to the above questions it is crucial to note that pastoral counselling, diagnosis and interpretation take a variety of forms depending on the context. Augsburger (1986:16) correctly maintains that Christian caring is altered radically by its context though the goal is maintained. He argues that it is difficult to name a common denominator. Some models are similar in certain contexts while other forms are unrecognisable to the Western eye: firstly in cultures where most problems are resolved within the joint family; secondly where the vertical patterns of filial piety depend on the wisdom of elders; and thirdly where conversations on problems of living occur in informal rather than contractual settings. For pastoral counselling and diagnosis to be meaningful, it is thus suggested to be grounded in socio-cultural systems thinking. Pastoral counselling should take people's contexts seriously; and in order for pastoral counselling and diagnosis in Africa to be effective, knowledge of the African worldview is crucial for interpreting the conversation.

The argument here is that a pastoral counsellor in Africa should be aware of the crucial role played by the African worldview in order to have meaningful diagnosis. The worldview provides the schema for probing and interpreting the conversation. In the following sections, an attempt will be made to outline firstly the nature and function of pastoral diagnosis; and secondly the perceived causes of distress and suffering in Africa. Finally, possible areas for probing and interpretation in an African context shall be proposed.

\section{The nature and function of pastoral diagnosis}

Pastoral diagnosis seeks to understand and analyse the quality of an individual's faith and spirituality. Charles Taylor (1991:61-80) calls this process, "theological assessment". The events taking place in a person's life are understood from a Christian faith perspective, that is, eschatological. An assessment of faith is done in terms of God-images and life's ultimate meaning. However, this does not mean that emotions and experiences are ignored; rather, they are put in a theological frame.

The notion of pastoral diagnosis, however, is heavily contested. Many scholars hold different views on the issue, while others completely reject the notion. Pruyser (1976:39) believes that Carl Rogers' negative evaluation gave an uncalled-for unilateral and negative connotation to diagnosis. Without delving into the discussion of how diagnosis is usually misunderstood, it should be emphasised that "a diagnosis does not focus on a procedure of classification through which behaviour is categorised and typologised in advance" 
(Louw, 1998:300). It is not about prescribing and explaining human beings' complexities but an attempt to gain insight, understanding and clarity of a person's problem. Thus despite the diverse views and scepticism on the issue, Pruyser, like many other practitioners, is convinced that diagnosis is a substantial part of pastoral counselling. De Jongh van Arkel's research (1987), cited by Louw (1998:300), confirms the importance of pastoral diagnosis. He points out that it helps the pastor in the process of organising and connecting with relevant data and in generating hypothesis, in the light of which both pastor and parishioner can apply the truth of Scripture more effectively to certain areas of the parishioner's life. Pastoral diagnosis then, sheds light on all relevant data.

In A mature faith therefore, Louw (1999:23) summarises the meaning of diagnosis by clarifying that a diagnosis does not focus on a procedure of classification through which behaviour is categorised and typologised in advance. Diagnosis is simply the interpretation of the person's total existence. It focuses on clarification, establishing connections, organising data and interpreting behaviour in terms of the quest for meaning. Focus on the organising, summarising and interpretation of data enables a pastoral diagnosis to establish links between faith and life; between God-image and self-understanding; between Scriptural truth and existential context (italics - VM). Thus Louw, like Crabb (1979), Clinebell (1984) and many other pastoral counsellors, stresses that pastoral diagnosis focuses on the interplay between faith and life issues in all its dimensions. It namely focuses the effect which faith has on: a person's emotional processes (affective dimension); the association between faith and personal motivation (conative dimension); faith as a form of knowledge - rational component (cognitive dimension); faith and the existing concepts, ideas and perceptions (experiential dimension); faith and ethics (ethical dimension); and faith and socio-political dimension (contextual dimension).

In faith assessment, the following categories are analysed: a mature faith - an analysis of faith; commitment and practice - religious analysis; God images - theological analysis of God concepts; and experiences of God. An analysis of faith would seek the suffering person's responses in his/her situation regarding the following: the intensity and degree of suffering; negativity and feelings of guilt; the quest for meaning; maturity in faith; belief and content of faith, assessing faith types; a test of virtue. Questions regarding the situation are asked and responses are analysed. 
Religious analysis seeks to determine the character of parishioners' commitment, which entails practices and rituals. Religion can be disfunctional such as the following: artificial religion (religion as superstition); conventional religion (religion as tradition); legalistic religion (religion as duty); neurotic religion (religion as an obsessive factor for perfection); and pathological religion (religion as an alienating factor). Religion can also be constructive, that is, mature religion or religion as doxology. In this case religion fosters purposefulness and responsible action.

Theological analysis of God-images seeks to assess the individual's understanding of God by determining the content of his/her God images. The images develop through a person's experiences of God in real-life events and through the reading of Scripture. However, when diagnosing people, counsellors should recognise that they have their own image of God based on their own experiences; they have an ecclesiastical tradition, and they should therefore be sensitive to the counsellee's concept of God. The diagnosis should not be ethical, being concerned about good or bad.

As the person tells his/her story, the counsellor should do a story analysis of God images, funny stories, tragic stories, romantic stories, ironic stories, dramatic stories and therapeutic stories (Louw, 1998:332). Apart from the story analysis, there are four assessment models - the metaphorical model, the experiential theodicy model, the pastoral semantic model, and the thematic model. The counsellor can employ any of the models, depending on the circumstances that the counsellee faces. For instance, the experiential theodicy model would be best in crisis counselling.

In assessing these faith aspects pastoral counsellors have proposed various models. Crabb (1979:169) proposed a seven-stage model. 2 Capps (1984:66-69) proposed six diagnostic types in pastoral counselling, which he calls "theological diagnosis", 3 and Clinebell

2 Identify problem feelings; identify problem behaviour; identify problem thinking; clarify Biblical thinking; secure commitment; plan and carry out Biblical behaviour; and identify Spirit-controlled feelings.

3 Theological diagnosis as identifying underlying personal motivations; theological diagnosis as identifying the range of potential causes; theological diagnosis as exposing inadequate formulations of the problem; theological diagnosis as discovering untapped personal and spiritual resources; theological diagnosis as bringing clarity to the problem; and theological diagnosis that assesses a problem in terms of the deepest intentions of shared human experience. 
(1984:31) proposed a holistic growth diagnosis model. 4 Clinebell maintains that diagnosis seeks to determine where there is a problem in relationships in order to foster growth and develop spirituality, which is the centre of the model. A further model proposed is the life story (narrative), which has a premise that past religious experiences influence the way in which a person deals with problems. McKeever's model cited by Louw (1998:309) is an example of this model. In a story model the pastor should hear the individual's life story, since the problem is embedded within a broader field of historical events. Furthermore, Louw notes that Fowler proposes a developmental stage model that defines faith in terms of its consequences on human behaviour.

These various diagnostic models are an attempt to understand the effect of faith on parishioners' life. The diversity of the models reveals that diagnosis in pastoral counselling is complex. But what could be noted is that diagnosis is a process of understanding. It is done through using systematised relevant data, integrated knowledge, and parishioner's faith language regarding the connection between belief system and everyday existential experiences. The pastoral counsellor focuses on problem thinking and problem behaviour, historical context and life story, ego-strength and purposefulness, social analysis, coping skills and temporal events, interplay between motive, need and expectation (vocation), and the ethical dimension (Magezi, 2005:173-174; Louw, 1998).

However, of these various diagnostic dimensions, historical context and social analysis are critical for pastoral interpretation in Africa. Distress is linked to one's environment. Diagnosis therefore should focus on a person's history or life history. Family history and patterns of interaction are important pieces of information for understanding faith patterns. Community structures and the nature of existing relations should be analysed for a better understanding of faith behaviour. A breakdown in a relationship is a source of distress. The challenge of pastoral diagnosis in Africa, therefore, is to develop an interpretational frame in which assessment focuses on interpreting the influence of the complex network of relationships.

4 Clinebell views the role of care and counselling as empowering growth towards wholeness in all of the six interdependent aspects of a person's life. The six dimensions are enlivening one's mind, revitalising one's body, renewing and enriching one's intimate relationships, deepening one's relationship with nature and the biosphere, growth in relation to the significant institutions in one's life, and deepening and vitalising one's relationship with God. 
Furthermore, the culture is hierarchical with elders playing a key consultation and counselling role, which renders some confrontational techniques such as probing, less effective. The question which arises therefore, is: how can a thorough understanding of the African worldview be used to furnish pastoral diagnosis and interpretation in Africa.

\section{Towards a pastoral interpretation for Africa}

\subsection{African worldview and perception of suffering}

The concept of worldview has been the subject of many scholarly discussions. Generally, the term is used to refer to the common concept of reality shared by a particular group of people, commonly referred to as a culture, or an ethnic group. Worldview is both an individual and a group phenomenon (Boyd, 1999; 2006). Van der Walt (1994:40-41) further describes a worldview, saying that it encompasses man's whole life; it is a mode of looking or seeing; guides our understanding of the world; reveals unity; it is both descriptive and prescriptive; requires full commitment; is typically human, and is prescientific, among other characteristics. The African worldview therefore is understood to be built on the integration of all aspects of life in an interconnected and mutually dependent world, with the following central elements: the belief in one supreme God; a cosmos that is rich in spiritual forces - such as the ancestors; human beings in human community in an unbroken relationship with this spiritual reality; and an intimate relationship with the land, and with all living things. In this African worldview the whole is always seen in the part (World Council of Churches, 2004). 5

Magezi (2006) argued, in agreement with other African scholars, that any form of distress in Africa is perceived to be caused by supernatural beings. Offending God or ancestors, and breaking taboos or customs evoke punishment, which manifests in the form of distress. At times sickness and suffering is attributed to an offence against the gods, against spirits of the ancestors and the living dead, and other mysterious forces. At times it could also be witchcraft,

5 Declaration by the participants to the 3rd Consultation on Africa's Contribution to the Religious and Spiritual Heritage of the World, convened by WCC and PCID in Addis Ababa Ethiopia from 13th to 17th September 2004. The consultation comprised ten African countries: Ethiopia, Gambia, Ghana, Kenya, Nigeria, Senegal, South Africa, Sudan, Tanzania, Zimbabwe and from the diaspora: Brazil, Iraq, Jamaica, Trinidad and Tobago and the USA. 
sorcery or enemies with magical powers that cast misfortunes (Berinyuu, 1988; Kasambala, 2004; Kiriswa, 2002; Mwaura, 2000).

Therefore, in cases of misfortune such as miscarriage, failure to conceive, sickness, suffering or any form of distress, treatment is through ritual purification, exorcism or sacrifices. Relationships have to be maintained, starting with the nuclear family, moving outwards to the extended family, the clan, the tribe, gods, and spirits. Counselling is sought from the respective elders who then advise the individual or family on the appropriate rites, exorcism, sacrifice, purifications and confessions to restore the balance. Kiriswa (2002:30) rightly states that it is believed that without a ritual performance the person would not experience psychological healing. A ritual confirms that the person receives the necessary attention and healing.

Moreover, Kiriswa (2002) claims that African counselling is a type of hospitality that is only measured by the kindness, warmth and friendship of the counsellor. Distress of any member in the community is never taken for granted. The health of a person is the responsibility of the whole community. The well-being of one means the well-being of all; when they celebrate, they do it together, and when tragedy occurs, they grieve together. A healing ritual as a balance-restoring exercise signifies support, concern, love and a sense of belonging. Therefore, to avoid practices that may harm or destabilise the system, an experienced and elderly person (not a youth), should be consulted for counselling or advice in order to preserve the community. Rituals that are meant to restore balance are performed in a communal context and through these, the sick persons regain self-acceptance and a sense of belonging. They realise that they are not alone in the journey through the challenges of life, that there are people to support and encourage them and in whom they can confide when trouble arises.

In another attempt to contextualise and capture the role of a pastoral counsellor in Africa, Berinyuu (1988) and Mwaura (2000) suggest that a pastoral counsellor should assume the role of a diviner. The counsellor, just as a diviner, should listen to people's stories and interpret them. Thus, story telling and listening are crucial in African counselling. The stories are captured in proverbs, idioms and symbols that the counsellor (diviner) should be able to interpret (Kasambala, 2004). The counsellor should be able to listen and try to "fix the puzzle" by probing inconsistencies in the story. McKeever's narrative 
model6 rightly focuses on stories of life to attain insight into parental education and religious experiences. Louw also views story analysis as critical in understanding a counsellee's God-images. Therefore, how may this knowledge provide guidance and interpretational insight to the counselling conversation?

\subsection{Centrality of worldview in interpreting a pastoral conversation}

As observed in the foregoing, some of the defining elements of African worldview are community with and belief in supernatural beings. In my opinion, these appear to be the crucial elements on which the other elements hang. Several African literature on society, the individual, family, religion, philosophy and other related themes in the influential works of Senghor (1963), Mbiti (1969; 1992) and many others, attest to this fact. Pastoral diagnosis should therefore assess the constructive or destructive tendencies of these elements.

It stands to reason that due to the practice of oral tradition and the low literacy level in Africa, story analysis is critical in diagnosis. However, this may prove contrary to diagnosis in other contexts, especially in the West where a confrontational approach may be effective. In Africa, people usually do not open up unless the counsellor is aware of areas to probe. Furthermore, when a counsellor is told a story he/she is expected to provide the right advice. In consideration of this cultural distinction, the challenge for the pastoral counsellor is to create an atmosphere in which an individual may open up freely. And as the counsellee tells his/her story the counsellor needs to be very attentive. The counsellor should have an accurate knowledge and understanding of the causes of distress in order to interpret the conversation effectively and meaningfully.

However, while the value of story analysis in Africa is crucial it is sometimes over-emphasised, as evidenced in Berinyuu (1988) and Kasambala (2004), among many others. The over-emphasis on stories has a danger of elevating them to become complete documents or texts that can easily be read, analysed and interpreted, and then intervened. It seems this over-emphasis on stories is an attempt to come up with a uniquely African counselling approach. In doing so, however, the centrality of the African world-

6 In Louw (1998). 
view in diagnosis is under-emphasised, though, stories are analysed based on worldview. It is therefore strongly suggested that a counsellor should listen to stories in order to focus probing. This implies that listening for probing is equally critical.

To illustrate the crucial role of worldview in pastoral interpretation in Africa, let us consider the following example:

Peter grew up in a village. His parents insisted that he should not marry from a certain tribe. When Peter went to college he met Jane from the forbidden tribe and fell in love with her. Despite his father's disapproval, as a Christian (new person in Christ) he married Jane. However, when five years elapsed without conception, they began to have conflicts. Jane put pressure on Peter to inquire from his parents the possible cause of their problem.

On the surface, this story could be treated only as a misconception problem. But to understand it in this way would be to pluck it out of the African context and worldview. The story requires one to understand the worldview of the people. The issues in the story that the pastor may need to be aware of and explore in order to counsel this couple could be one of the following:

- The relationship between Peter and his parents, which Jane might conclude as the cause of the problem (that is because of the belief that disobedience to parents brings misfortune or a bad spell).

- Directly connected to the issue of relationship is the belief that the situation could be addressed (possibly through a ritual or sacrifice to restore the relationship). It is possible Jane feels very strongly about this if her level of Christian maturity is low.

- The counsellor may also need to explore their worldview regarding marriage and children. In most misconception cases the woman is the one blamed for the infertility, therefore, Jane has to clear her name. The couple's view on children in this case should be explored.

Another example of a statement that may underscore the crucial role of a worldview in interpretation is that in the event of a crisis like death, job loss, or sickness, some people may ask the individual: "Have you consulted the elders?", or "What are the elders saying about this situation?" The question usually implies that one should consult parents or elders for divination in order to determine the cause of the crisis. 
The pastoral counsellor in Africa needs to thoroughly understand the various dimensions of a crisis and listen to stories with the intention of getting "clues" or "sign-posts" for avenues to probe (based on knowledge of the worldview). Thus a thorough knowledge of African worldview is vital for the counsellor to be able to read behind the story. These perceptions, however, are often clouded and unclear especially to the counsellor who is unaware of the worldview. Tebogo Mazibuko (2004), in her presentation on Ubuntu, rightly pointed out that African beliefs and practices are not talked about as much as they are lived, which means that one may miss the point by focusing on the narrative only. For instance, some African Christians may confess Christ during the day and consult diviners at night; they are commonly referred to as "day Christians". A pastoral counsellor ought to be aware of the worldview in order to listen for indicators in stories that can be probed to be able to gain clarity and understand the underlying issues. Even though stories are invaluable, one should be aware that story analysis is only a part of the long process of assessment and analysis.

In a significant way, Kasambala (2004:159-60) focuses on African diagnosis by proposing a six-phased model which offers guidelines on African assessment and interpretation. The phases are: discerning, clarifying, interpreting, supporting, reflecting and responding. The model highlights important focal areas in interpreting African people's stories. However, Kasambala, (in the same vein as Berinyuu (1988), and some other African counselling writers) overlooks or "over-assumes" the crucial complexity of community influence in counselling. My proposal here is that for effective pastoral counselling to occur in Africa, the counsellor needs to determine the constructive and destructive role of the affected person's community, that is the network of relationships. The reason is that effective and meaningful counselling occurs within the context of intertwined relationships.

One major reason that causes Africans to oscillate between Christianity and traditional practices, thereby hindering effective pastoral healing, is community or extended family pressure. When one goes through distress, the pressure to conform to community advice and practices that may be against Christian practices is very high. Refusal to conform may cause expulsion from the circle of relationships, which aggravates distress. Ncube (2003:91) rightly argues that African practices of coping are embedded in the realm of community practices. The family or the community walks the journey with the person in distress through rituals and sacrifices. 
In the light of these issues, pastoral diagnosis in Africa should focus on at least two key issues in relation to faith, namely the role of the community and supernatural causes of distress. The community performs either a constructive or destructive role in the process of coping. The supernatural perception of distress should be established and be challenged.

Consequently, two fundamental questions may be posed at this point: What kind of questions should a pastoral counsellor ask in order to determine the constructive or destructive role of the community during a pastoral conversation? How should responses from these questions be analysed and interpreted to clarify the influence of the network of relationships? What kind of responses might indicate a strong belief in supernatural causes of distress that a pastoral counsellor should challenge?

In response to the above questions, the Table below and the interpretations which follow propose examples of questions that a pastoral counsellor may ask in order to determine the influence of the network of relationships and a belief in a supernatural worldview. The questions focus on family background and religion, which are key areas of assessment in Africa.

\begin{tabular}{|c|c|c|c|c|}
\hline \multirow{7}{*}{$\begin{array}{l}\text { Family back- } \\
\text { ground, up- } \\
\text { bringing and } \\
\text { social } \\
\text { interaction }\end{array}$} & $\begin{array}{l}\text { 1. Are you the first Christian in the } \\
\text { family? }\end{array}$ & Yes & \multicolumn{2}{|l|}{ No } \\
\hline & $\begin{array}{l}\text { 2. If yes in } 1 \text {, to what extent are your } \\
\text { parents supportive of your faith? }\end{array}$ & Not at all & Little & Very \\
\hline & $\begin{array}{l}\text { 3. Are your parents the first } \\
\text { Christians in the extended family? }\end{array}$ & Yes & \multicolumn{2}{|l|}{ No } \\
\hline & $\begin{array}{l}\text { 4. If yes in } 3 \text {, how supportive is the } \\
\text { extended family? }\end{array}$ & Not at all & Little & Very \\
\hline & $\begin{array}{l}\text { 5. Did you ever participate or witness } \\
\text { an ATR } 7 \text { ancestral ceremony with } \\
\text { parents? }\end{array}$ & Yes & \multicolumn{2}{|l|}{ No } \\
\hline & 6. If yes in 5 , how often? & Once & $\begin{array}{l}\text { A few } \\
\text { times }\end{array}$ & $\begin{array}{l}\text { Many } \\
\text { times }\end{array}$ \\
\hline & $\begin{array}{l}\text { 7. Are you and your family dependent } \\
\text { on, or influenced by, the extended } \\
\text { family? }\end{array}$ & Yes & \multicolumn{2}{|l|}{ No } \\
\hline
\end{tabular}




\begin{tabular}{|c|c|c|c|c|c|}
\hline & $\begin{array}{l}\text { 8. If yes in } 7 \text {, what is the level of } \\
\text { influence? }\end{array}$ & Little & \multicolumn{2}{|c|}{ Moderately } & Much \\
\hline & $\begin{array}{l}\text { 9. Did you grow up in a city or rural } \\
\text { village? }\end{array}$ & City & \multicolumn{3}{|l|}{ Village } \\
\hline & $\begin{array}{l}\text { 10. If a city in } 9 \text {, how often do you } \\
\text { visit the rural village? }\end{array}$ & Never & $\begin{array}{l}\text { Once a } \\
\text { year }\end{array}$ & \multicolumn{2}{|c|}{$\begin{array}{l}\text { Two or } \\
\text { more } \\
\text { times a } \\
\text { year }\end{array}$} \\
\hline & $\begin{array}{l}\text { 11. Which type of school did you } \\
\text { attend? }\end{array}$ & Government & Mission & \multicolumn{2}{|c|}{ Private } \\
\hline & $\begin{array}{l}\text { 12. At what level did you attend the } \\
\text { school mentioned in 11? }\end{array}$ & Primary & \multicolumn{3}{|c|}{ High school } \\
\hline & 13. What is your level of education? & $\begin{array}{l}\text { Less grade } \\
10\end{array}$ & Matric & \multicolumn{2}{|c|}{$\begin{array}{l}\text { College/ } \\
\text { university }\end{array}$} \\
\hline \multirow{8}{*}{ Religion } & 14. Do you believe in dreams? & Yes & \multicolumn{3}{|l|}{ No } \\
\hline & 15. If yes in 13 , how strongly? & Little & \multicolumn{2}{|c|}{ Moderately } & Very \\
\hline & $\begin{array}{l}\text { 16. Do you believe in supernatural } \\
\text { influence (ancestors, spirits or } \\
\text { witches)? }\end{array}$ & Yes & \multicolumn{3}{|l|}{ No } \\
\hline & 17. If yes in 15 , how strongly? & Little & \multicolumn{2}{|c|}{ Moderately } & Very \\
\hline & $\begin{array}{l}\text { 18. Do you think Christianity is a } \\
\text { Western religion? }\end{array}$ & Yes & \multicolumn{3}{|l|}{ No } \\
\hline & $\begin{array}{l}\text { 19. Do you think there is, or can be, a } \\
\text { relationship or link between } \\
\text { ancestors and Jesus? }\end{array}$ & Yes & \multicolumn{3}{|l|}{ No } \\
\hline & $\begin{array}{l}\text { 20. Do you remember the } \\
\text { circumstances of your salvation? }\end{array}$ & Yes & \multicolumn{3}{|l|}{ No } \\
\hline & \multicolumn{5}{|l|}{ 21. Why do you think you are a Christian? } \\
\hline
\end{tabular}

The above questions may help in interpreting stories and probing in the following ways:

\section{- Family background:}

If a person is the first Christian in a family, it may imply that the person grew up practising African traditional practices and when this individual experiences suffering, the temptation to turn back is strong. The situation may be exacerbated by parents who may not be Christians, but apply pressure to force him to recant. The person may end up oscillating between two worlds (syncretism), thereby hindering healing. The same may happen to the nuclear family. If 
the family of the person in distress is the first Christian family in the extended family, the opposing pressure can be great. When suffering or a crisis such as death occurs, the extended family may be apathetic, since they believe the person invited trouble for him- $/$ herself by forsaking the traditions. This may intensify and aggravate the suffering. In such a situation koinonia support is critical.

Furthermore, the people in African contexts who often participate in or witness traditional practices may consider these practices a solution in times of sickness and suffering. When the extended family is highly influential on the nuclear family, there is greater pressure from the extended family to seek alternative means to resolve the crisis and suffering. The environment also exerts considerable influence.

Traditional practices do not have a very strong influence on Africans who grow up in cities and are exposed to Western culture. However, this assumption does not always hold, so the counsellor should probe further because this may not automatically imply that they are more spiritual than rural dwellers. Even though they might have lost the traditional influences, some are still not Christians. Schools attended and the level of education may also be an avenue to explore. People who attended mission schools (that is, churchowned schools started by missionaries) are normally more exposed to Christianity than those who attended government schools. Private schools indicate a high social status and these scholars could reflect a loose attachment to traditional practices. Furthermore, the traditional ties of those who study up to a tertiary level are usually weakened.

\section{- Religion and supernatural beliefs:}

Strong beliefs in dreams, ancestors, spirits or witches are a big hindrance to pastoral healing. People with such beliefs are more likely to be tempted to seek traditional solutions to problems. When there is scepticism about the Bible and Christianity, this may certainly mean that the level of influence of the God of the Bible and the acceptance of Christianity are very low.

The family background and religion are explored and interpreted in the light of faith. Links between the Christian faith and family history and religious beliefs should be established. The questions are: How do these people understand God in their situation, (God-image)? To what extent does the Scriptural truth of God influence the people's interpretation of their existential situation? At stake here is the perception of God (God images), which may play a constructive or 
destructive role that the counselor needs to determine. In this situation the questions are: What should be the role of koinonia? Which is the context of pastoral care and counselling in the light of the potential family conflict? How may a parishioner be counselled in order to foster vivid hope and meaning?

It should be noted that the questions proposed for diagnosis which would enable the counsellor to analyse African's stories and responses, are merely examples of how a pastoral counsellor can probe during a counselling encounter. These questions are applicable to different kinds of distresses but should in no way be adopted prescriptively, since they have not been validated by empirical research. If tested, however, they may open other avenues which may indicate where the counsellee stands spiritually.

\section{Conclusion}

This article argues for the centrality of an African worldview in interpreting a pastoral conversation. In doing so, it describes the distinctive nature and function of pastoral diagnosis and proposes an approach to the interpretation of a pastoral conversation in Africa. The knowledge of the African worldview as a key to the diagnosis and interpretation processes is brought into view and it is argued that the two key areas in need of exploration within this frame are the family and the religious background.

\section{List of references}

AUGSBURGER, D.W. 1986. Pastoral counselling across cultures. Philadelphia: Westminster.

BENNER, D.G. 1992. Strategic pastoral counselling: a short-term structured model. Grand Rapids: Baker.

BERINYUU, A.A. 1988. Pastoral care to the sick in Africa: an approach to transcultural pastoral theology. Frankfurt: Peter Lang.

BOYD, JENKINS. 2006. What is worldview? http://orvillejenkins.com/ worldview/worldvwhat.html Date of access: 25 May 2007.

CAPPS, D. 1984. Pastoral care and hermeneutics: theology and pastoral care. Philadelphia: Fortress.

CLINEBELL, H. 1984. Basic types of pastoral care counselling: resources for the Ministry of Healing and Growth. Nashville: Abingdon.

CRABB, L.J. 1979. Effective Biblical counselling. Michigan: Grand Rapids.

KASAMBALA, A.E. 2004. The interplay between God-images and healing in pastoral ministry: engaging an African spirituality. Stellenbosch: University of Stellenbosch. (D.Th. dissertation.)

KIRISWA, B. 2002. Pastoral counselling in Africa: an integrated model. Eldoret: AMECEA Gaba. 
LARTEY, E.Y. 1997. In living colour: an intercultural approach to pastoral care and counselling. London: Cassell.

LOUW, D.J. 1998. A pastoral hermeneutics of care and encounter. Cape Town: Lux Verbi.

LOUW, D.J. 1999. A mature faith: spiritual direction and anthropology in a theology of pastoral care and counselling. Louvain: Peeters.

MAGEZI, V. 2005. Life beyond infection: home-based care to HIV-positive people within a context of poverty. Stellenbosch: University of Stellenbosch. (D.Th. dissertation.)

MAGEZI, V. 2006. Community healing and the role of pastoral care of the ill and suffering in Africa. In die Skriflig, 40(3):505-521.

MAZIBUKO, TEBOGO. 2004. A paper co-presented with Cornell Drucilla in sociology: "A call for a nuanced constitutional jurisprudence: ubuntu, dignity, and reconciliation", July 23.

MBITI, J.S. 1969. African religions and philosophy. New York: Praeger.

MBITI, J.S. 1992. Introduction to African religion. 2nd ed. Nairobi: East African Publishers.

MWAURA, P.N. 2000. Healing as a pastoral concern. (In Waruta, D.W. \& Kinoti, H.W., eds. Pastoral care in African Christianity. Nairobi: Acton. p. 72-100.)

NCUBE, V.S. 2003. Responsibility in inculturation: the healing ministry in a Zulu context. (In Bate, Stuart C., ed. Responsibility in a time of AIDS: a pastoral response by Catholic theologians and AIDS activists in Southern Africa. Pietermaritzburg: Cluster. p. 78-115.)

PRUYSER, P.W. 1976. The minister as diagnostician: personal problems in pastoral perspective. Philadelphia: Westminister.

SENGHOR, L. 1963. Negritude and African socialism. (In Kirkwood, K, ed. St. Anthony's papers. Vol. 15. London: Oxford University Press. p. 16-22.)

TAYLOR, C.W. 1991. The skilled pastor: counselling as the practice of theology. Minneapolis: Fortress.

VAN DER WALT, B.J. 1994. The liberating message: a Christian worldview for Africa. Potchefstroom: PU for CHE. Institute for Reformational Studies.

WORLD COUNCIL OF CHURCHES. 2004. Current dialogue issue 44, December 2004. Declaration by the participants to the 3rd Consultation on Africa's Contribution to the Religious and Spiritual Heritage of the World, convened by WCC and PCID in Addis Ababa Ethiopia from 13th to 17th September 2004. http://www.wcccoe.org/wcc/what/interreligious/cd44-03 html Date of access: 25 May 2007.

\section{Key concepts:}

counselling and African worldview

pastoral assessment and interpretation in Africa

pastoral counselling and community in Africa

pastoral diagnosis in Africa 


\section{Kernbegrippe:}

berading en Afrika-wêreldbeskouing pastorale berading en die gemeenskap in Afrika pastorale diagnose in Afrika pastorale ondersoek en interpretasie in Afrika 